\title{
PERANCANGAN INSTALASI PENERANGAN PADA GEDUNG LABORATORIUM DAN PERKULIAHAN TERPADU UNIVERSITAS BORNEO TARAKAN
}

\author{
Aprizulkifli ${ }^{1}$, Sugeng Riyanto ${ }^{2}$ \\ ${ }^{1,2}$ Teknik Elektro, Universitas Borneo Tarakan \\ ${ }^{1}$ aprizulkifli@gmail.com \\ ${ }^{2}$ sugeng072.sregmail.com
}

\begin{abstract}
The design of the lighting installation in the Integrated Lecture and Laboratory Building of the University of Borneo Tarakan. Generates a total power of about 31,048 $K W$ with MCCB capacity on the main panel of $150 \mathrm{~A}$. In this building is divided into 3 floors $(1,2$ and Top Floor). Each group has its respective power $(18,400,12,328$ and 320 Watt) and the nominal currents of each group are $(35,35$, and 2 Ampere). The resulting stress loss is $0.4 \%$.
\end{abstract}

Keywords - Electricity, Lighting Installation

Intisari-Perancangan instalasi penerangan pada bangunan Gedung Laboratorium dan Perkuliahan Terpadu Universitas Borneo Tarakan. Menghasilkan total daya sekitar 31,048 KW dengan kapasitas MCCB pada panel utama 150 A. Pada gedung ini dibagi menjadi 3 Lantai (1, 2 dan Top Floor). Pada setiap kelompoknya memiliki daya masing-masing (18.400, 12.328 dan 320 Watt) dan arus nomilnal masing-masing kelompok adalah $(35,35$, dan 2 Ampere). Susut tegangan yang dihasilkan adalah 0,4\%.

Kata Kunci-Listrik, Instalasi Penerangan.

\section{Pendahuluan}

Listrik memiliki peran yang sangat penting dalam kehidupan sehari-hari. Semakin bertambahnya jumlah penduduk maka semakin besar pula energi listrik yang diperlukan untuk memenuhi kebutuhan tersebut. Hal ini bisa kita lihat dari kehidupan sehari-hari, hampir setiap bangunan membutuhkan energi listrik seperti sekolah atau kampus, perkantoran, rumah sakit, hotel, dan sebagainya. Dalam oprasionalnya, gedung-gedung bertingkat tersebut pasti memerlukan sistem perancangan instalasi penerangan yang baik dan berkualitas. Instalasi penerangan merupakan suatu instalasi listrik yang bebannya merupakan komponen penerangan. Rangkaian instalasi penerangan terdiri dari beberapa komponen listrik yang saling terhubung dari sumber listrik ke beban yang terletak pada suatu tempat atau ruangan tertentu. Instalasi penerangan umumnya dirangkai dari beberapa titik cahaya sehingga dapat terbentuk suatu sistem yang mempunyai fungsi untuk menerangi suatu tempat. Untuk merancang suatu sistem rangkaian untuk instalasi penerangan, kita harus mempunyai rencana pemasangan sehingga mempunyai acuan dalam pemasangan instalasi tersebut. Selain itu suatu instalasi penerangan dapat berfungsi dengan baik dan aman apabila memenuhi syarat pemilihan pengaman dan juga penghantar. Maka dari itu, seorang perencana haruslah memahami betul peraturan- peraturan yang berlaku untuk setiap pemasangan instalasi listrik khususnya pada instalasi penerangan. Untuk mengetahui persyaratan umum instalasi listrik agar dapat merancang suatu rangkaian yang aman dan baik, dapat berpedoman pada standar Persyaratan Umum Instalasi Listrik (PUIL) 2000.

Gedung Laboratorium dan Perkuliahan Terpadu Universitas Borneo Tarakan merupakan salah satu gedung bertingkat yang ada di universitas borneo tarakan yang dalam tahap pembangungan. Untuk menunjukan kenyamanan pada dosen, mahasiswa, dan civitas akademik, gedung tersebut memerlukan sistem perancangan instalasi penerangan yang baik sesuai dengan standar Persyaratan Umum Instalasi Listrik (PUIL) 2000. Maka dalam tugas akhir ini penulis mengambil judul "Perancangan Instalasi Penerangan pada Gedung Laboratorium dan perkuliahan terpadu Universitas Borneo Tarakan".

\section{LANDASAN TEORI}

\section{A. Instalasi Penerangan}

Instalasi penerangan merupakan suatu instalasi listrik yang bebannya merupakan komponen penerangan. Rangkaian instalasi penerangan terdiri dari beberapa komponen listrik yang saling terhubung dari sumber listrik ke beban yang terletak pada suatu tempat atau ruangan tertentu. Instalasi penerangan umumnya dirangkai dari beberapa titik cahaya sehingga dapat terbentuk suatu sistem yang mempunyai fungsi untuk menerangi suatu tempat. Maka dari itu, seorang perencana haruslah memahami betul peraturan-peraturan yang berlaku untuk setiap pemasangan instalasi listrik khususnya pada instalasi penerangan. Untuk mengetahui persyaratan umum instalasi listrik agar dapat merancang suatu rangkaian yang aman dan baik, dapat berpedoman pada standar Persyaratan Umum Instalasi Listrik (PUIL) 2000.

B. Indeks Ruangan

Indeks ruang atau indeks bentuk $k$ menjelaskan perbandingan antara ukuran-ukuran utama suatu ruangan berbentuk bujur sangkar:

$$
\begin{aligned}
& \mathrm{k}=\frac{\mathrm{pxI}}{\mathrm{hx}(\mathrm{p}+\mathrm{l})} \\
& \eta=\eta_{1}+\frac{\mathrm{k}-\mathrm{k}_{1}}{\mathrm{k}_{2}-\mathrm{k}_{1}} \mathrm{x}\left(\eta_{2}-\eta_{1}\right)
\end{aligned}
$$


Bidang kerja merupakan suatu bidang horizontal khayalan umumnya $0,80 \mathrm{~m}(80 \mathrm{~cm})$ di atas lantai. Nilai $\mathrm{k}$ yang dihasilkan tidak terdapat pada tabel efisiensi, penerangannya dapat ditentukan dengan interpolasi. Intensitas penerangan yang diperlukan ikut ditentukan oleh berat pekerjaan yang harus dilakukan. Juga panjangnya waktu kerja mempengaruhi intensitas penerangan yang diperlukan.

C. Intensitas Peneranga

Intensitas penerangan $E$ dinyatakan dalam satuan lux, sama dengan jumlah $1 \mathrm{~m} / m 2$, jadi flux cahaya yang diperlukan untuk suatu bidang kerja seluas Am2. Flux cahaya yang dipancarkan lampu-lampu tidak semuanya mencapai bidang kerja. Sebagian dan flux cahaya itu akan dipancarkan ke dinding dan langit-langit.

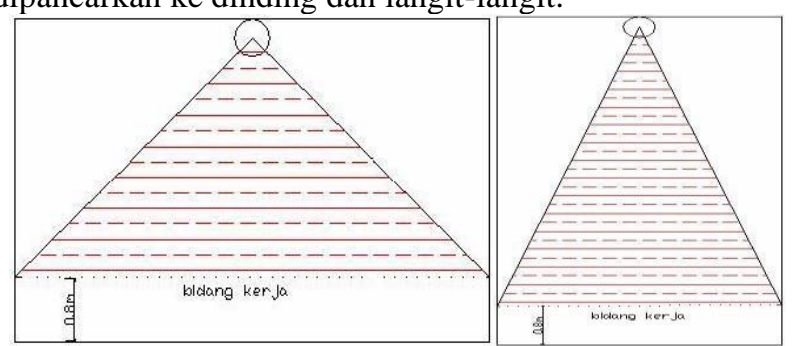

Gambar 1 Pembagian Flux Cahaya[1]

Untuk menghitung jumlah titik lampu pada ruangan, sebelumnya harus ditentukan terlebih dahulu data-data pada ruangan, antara lain:

1. Tinggi langit-langit $(\mathrm{t})$

2. Tinggi lampu terhadap bidang kerja (h)

3. Tinggi bidang kerja kurang lebih 0,8 meter

Sehingga didapat persamaan

$\mathrm{h}=\mathrm{t}-0,8 \mathrm{~m}$

Tabel 1

Intensitas Penerangan yang Diterbitkan Philips[1]

\begin{tabular}{|c|c|c|c|}
\hline No & Sifat Penerangan & $\begin{array}{l}\text { Penerangan } \\
\text { Sangat Baik }\end{array}$ & $\begin{array}{c}\text { Penerangan } \\
\text { Baik }\end{array}$ \\
\hline \multirow[t]{4}{*}{1} & Kantor & & \\
\hline & Ruang gambar & $2000 \operatorname{lux}$ & 1000 lux \\
\hline & Ruang kantor (pekerjaan biasa) & 1000 lux & $500 \operatorname{lux}$ \\
\hline & $\begin{array}{l}\text { Ruang yang jarang digunakan (arsip dan } \\
\text { ruang tunggu) }\end{array}$ & 250 lux & $150 \operatorname{lux}$ \\
\hline \multirow[t]{4}{*}{2} & Ruang sekolah & & \\
\hline & Ruang kelas & $500 \operatorname{lux}$ & 250 lux \\
\hline & Ruang gambar & 1000 lux & $500 \operatorname{lux}$ \\
\hline & Ruang administrasi & 1000 lux & $500 \operatorname{lux}$ \\
\hline \multirow[t]{4}{*}{3} & Industri & & \\
\hline & $\begin{array}{l}\text { Pekerjaan yang sangat halus (pembuat } \\
\text { jam tangan) }\end{array}$ & $5000 \operatorname{lux}$ & 2500 lux \\
\hline & Pekerjaan halus (bubut halus) & $2000 \operatorname{lux}$ & $1000 \operatorname{lux}$ \\
\hline & Pekerjaan biasa (pemasangan biasa) & $1000 \operatorname{lux}$ & 500 lux \\
\hline \multirow[t]{8}{*}{4} & Toko & & \\
\hline & Ruang jual dan pamer: & & \\
\hline & Toko-toko besar & 1000 lux & 500 lux \\
\hline & Toko-toko lain & $500 \operatorname{lux}$ & 250 lux \\
\hline & Etalase: & & \\
\hline & Toko-toko besar & $2000 \operatorname{lux}$ & 1000 lux \\
\hline & Toko-toko lain & 1000 lux & $500 \operatorname{lux}$ \\
\hline & Gudang & $500 \operatorname{lux}$ & 250 lux \\
\hline 5 & Masjid, Gereja, dsb & $250 \operatorname{lux}$ & 150 lux \\
\hline \multirow[t]{10}{*}{6} & Rumah tinggal & & \\
\hline & Ruang keluarga & $250 \operatorname{lux}$ & $150 \operatorname{lux}$ \\
\hline & Ruang tamu & 250 lux & $150 \operatorname{lux}$ \\
\hline & Koridor & $100 \operatorname{lux}$ & $50 \operatorname{lux}$ \\
\hline & Dapur & $250 \operatorname{lux}$ & $150 \operatorname{lux}$ \\
\hline & Kamar tidur & $250 \operatorname{lux}$ & 150 lux \\
\hline & Kamar mandi & $100 \operatorname{lux}$ & $50 \operatorname{lux}$ \\
\hline & Wc & $100 \operatorname{lux}$ & 50 lux \\
\hline & Gudang/garasi & 250 lux & $150 \operatorname{lux}$ \\
\hline & Penerangan umum & 250 lux & $150 \operatorname{lux}$ \\
\hline
\end{tabular}

D. Faktor Penyusutan/Depresiasi

Intensitas penerangan $\mathrm{E}$ dalam keadaan dipakai adalah intensitas penerangan rata-rata suatu instalasi dengan lampu-lampu dan armatur-armatur yang daya gunanya telah berkurang karena kotor, sudah lama tidak dipakai atau sebab-sebab lainnya. Efisiensi penerangannya diberikan pada tabel 2.3 di bawah ini.

Tabel 2

Efisiensi Penerangan dalam Keadaan Baru

\begin{tabular}{|c|c|c|c|c|c|c|c|c|c|c|c|c|c|}
\hline \multirow{4}{*}{$\begin{array}{l}\text { Armartur } \\
\text { penerangan } \\
\text { sebagian besar } \\
\text { langsung }\end{array}$} & \multirow[b]{2}{*}{$v$} & \multicolumn{10}{|c|}{ Efisiensi penerangan untuk keadaan baru } & \multicolumn{2}{|c|}{$\begin{array}{c}\text { Faktor depresiasi } \\
\text { untuk masa pemeliharaan }\end{array}$} \\
\hline & & & $r_{p}$ & 0,7 & & & 0,5 & & & 0,3 & & & \\
\hline & & k & 0.5 & 0,3 & 0,1 & 0.5 & 0,3 & 0,1 & 0,5 & 0,3 & 0,1 & 1 tahun 2 tahun & 3 tahun \\
\hline & $\%$ & & $\mathrm{Im}_{\mathrm{m}}$ & 0,1 & & & 0,1 & & & 0,1 & & & \\
\hline GCB & & 0,5 & 0,32 & 0,26 & 0,22 & 0,29 & 0,24 & 0.21 & 0,27 & 0,23 & 0,20 & & \\
\hline $2 \times$ TLF $36 \mathrm{~W}$ & & 0,6 & 0,37 & 0,31 & 0.27 & 0,35 & 0,30 & 0,26 & 0,32 & 0,28 & 0.25 & Pengotoran ringan & \\
\hline & & 0,8 & 0,46 & 0,41 & 0,36 & 0,43 & 0,38 & 0,35 & 0,40 & 0,36 & 0,33 & $0,90 \quad 0,80$ & 0,75 \\
\hline & & 1 & 0,53 & 0,48 & 0.44 & 0,49 & 0,45 & 0.42 & 0,46 & 0,42 & 0,39 & & \\
\hline & & 1.2 & 0,58 & 0,52 & 0,48 & 0,54 & 0,49 & 0,46 & 0,50 & 0,46 & 0,43 & & \\
\hline & & 1,5 & 0,62 & 0,58 & 0,54 & 0,58 & 0,54 & 0,51 & 0,54 & 0,51 & 0,48 & & 0,70 \\
\hline & 22 & 2 & 0,68 & 0,64 & 0,60 & 0,63 & 0,59 & 0,57 & 0,58 & 0,55 & 0,53 & & \\
\hline & $\uparrow$ & 2,5 & 0,71 & 0,67 & 0,64 & 0,66 & 0,63 & 0,60 & 0,61 & 0.59 & 0,57 & Pengotoran berat & \\
\hline & 87 & 3 & 0,73 & 0,70 & 0,67 & 0,68 & 0,65 & 0,63 & 0,63 & 0,61 & 0,59 & $x$ & $x$ \\
\hline & $\downarrow$ & 4 & 0,76 & 0,74 & 0,71 & 0,71 & 0,69 & 0,67 & 0,65 & 0,64 & 0,62 & & \\
\hline & 65 & 5 & 0,78 & 0,76 & 0,74 & 0,72 & 0,71 & 0,69 & 0,67 & 0,65 & 0,64 & & \\
\hline
\end{tabular}

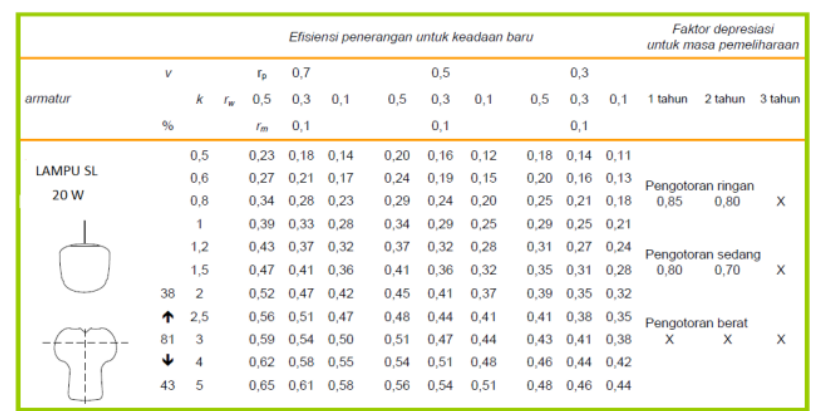

Faktor penyusutan atau faktor depresiasi $d$ adalah:

$$
d=\frac{E \text { dalam keadaan dipakai }}{E \text { dalam keadaan baru }}
$$

Faktor depresiasinya 0,8 suatu instalasi yang dalam keadaan baru 250 lux, akan menghasilkan 200 lux saja dalam keadaan sudah terpakai.

E. Beban dalam Ruangan

Dalam suatu ruangan yang harus diperhatikan adalah sistem penerangan lampu dan jumlah lampu yang dibutuhkan dalam suatu ruangan ditentukan dalam persamaan:

$$
\mathrm{n}=\frac{\mathrm{ExA}}{\phi x \eta \mathrm{xd}}
$$

\section{F. Menentukan Kapasitas Sekring}

Menentukan kapasitas skering / patron lebur atau pengaman pada pembagian tiap groub (kelompok) instalasi listrik fasa satu dengan tegangan 220 volt, maka arus yang mengalir menentukan kapasitas patron lebur atau pengaman pada Perangkat Hubung Bagi (PHB) instalasi listrik fasa tiga dengan tegangan 380/220 volt. Tabel 3

Patron Lebur atau Pengaman[1]

\begin{tabular}{|c|c|}
\hline Arus Nominal & Batas Waktu \\
\hline 2 dan 4 Ampere & 0,05 sekon \\
\hline 6 dan 10 Ampere & 0,1 sekon \\
\hline 16, 20 dan 25 Ampere & 0,15 sekon \\
\hline 35, 50 dan 63 Ampere & 0,2 sekon \\
\hline
\end{tabular}

Untuk menentukan kapasitas skering terdapat beberapa rumus persamaan untuk instalasi listrik fasa satu dan fasa tiga, yaitu: 


$$
\begin{aligned}
& \mathrm{In}=\frac{\mathrm{p}}{\cos \varphi \times \mathrm{VL} \times \sqrt{2}} \quad \text { untuk fasa tiga } \\
& \text { In }=\frac{\mathbb{P}}{\text { Vf } x \cos \varphi} \quad \text { untuk fasa satu }
\end{aligned}
$$

\section{G. Luas Penampang Kabel}

Luas penampang kabel pada perencanaan instalasi listrik harus memenuhi standar dan ukuran yang telah ditetapkan pada Persyaratan Umum Instalasi Listrik (PUIL) 2000.

$$
\mathrm{A}=\frac{2 \mathrm{x} \mathbb{R} I \mathrm{x} \cos \varphi}{\gamma \mathrm{Y} u}
$$

\section{H. Susut Tegangan}

Susut tegangan atau rugi tegangan terjadi karena adanya pergeseran arus listrik dengan saluran yang dialiri arus listrik tersebut. Karena saluran utama terdiri dari hantaran yang mempunyai hambatan serta induktansi. Susut tegangan tidak boleh melebihi 5\% dari tegangan pengenal pada terminal komponen (PUIL 2000), maka secara matematis susut tegangan atau rugi tegangan dapat dijabarkan sebagai berikut:

$$
\Delta \mathrm{V}=\frac{\left[2 \times \mathrm{Ix}\left(\mathrm{R}_{\mathrm{L}}^{t} \mathrm{x} \cos \varphi+\mathrm{x}_{\mathrm{L}}^{r} \mathrm{x} \sin \varphi\right) \mathrm{x} \mathrm{L}\right]}{1000}
$$

\section{METODE PENELITIAN}

\section{A. Tempat dan Waktu Penelitian}

Tempat penelitian tugas akhir ini adalah gedung baru Laboratorium dan Perkuliahan Terpadu Universitas Borneo Tarakan.

B. Metode Pengumpulan Data

Ini berupa pengumpulan data dalam perancangan ini adalah data yang berkaitan dengan gambar bangunan gedung, luas dan panjang setiap ruangan pada gedung Laboratorium dan Perkuliahan terpadu Universitas Borneo Tarakan.

\section{Diagram Alir Perancangan}

Diagram alir perancangan instalasi listrik ini menghitung indeks ruang, menghitung jumlah titik beban (lampu), menghitung kemampuan sekring, penampang kabel, dan rugi-rugi tegangan pada gedung Laboratorium dan Perkuliahan Terpadu Universitas Borneo Tarakan.

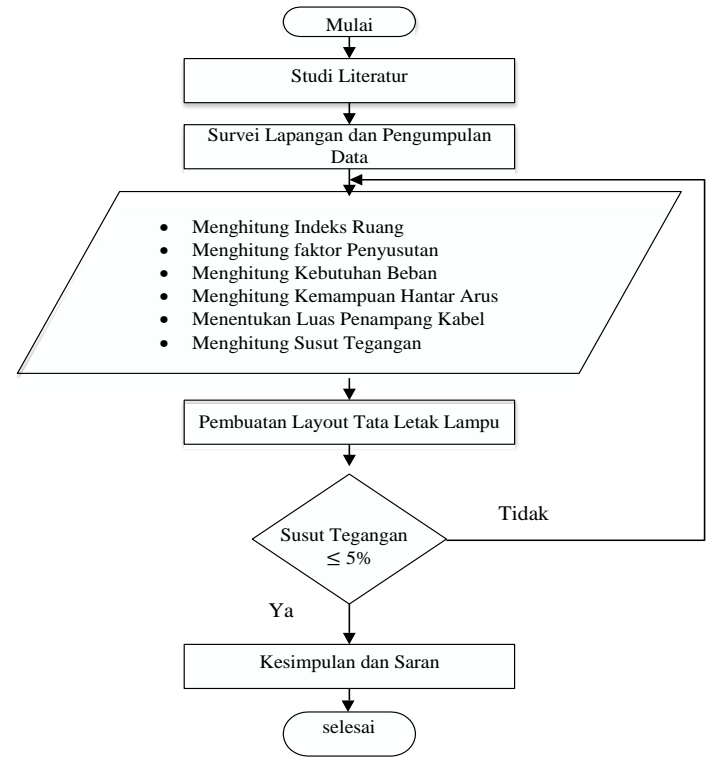

Gambar 2 Flowchart Diagram Alir Perancangan
D. Pengumpulan Data

Pengambilan data gambar gedung diperlukan sebagai acuan untuk melakukan perhitungan titik penerangan dan PHB.

\section{HASIL DAN PEMBAHASAN}

A. Perhitungan Instalasi pada Gedung Lantai 1 1. Ruang Komputer 1

\begin{tabular}{|l|c|c|c|c|c|}
\hline Ruangan & $\begin{array}{c}\text { Panjang } \\
\text { Ruangan } \\
(\mathrm{m})\end{array}$ & $\begin{array}{c}\text { Lebar } \\
\text { Ruangan } \\
(\mathrm{m})\end{array}$ & $\begin{array}{c}\text { Luas } \\
\text { Ruangan } \\
\left(\mathrm{m}^{2}\right)\end{array}$ & $\begin{array}{c}\text { Intensitas } \\
\text { Penerangan } \\
(\mathrm{E})(\text { Lux })\end{array}$ & $\begin{array}{c}\text { Faktor } \\
\text { Penyusutan } \\
(\mathrm{d})\end{array}$ \\
\hline $\begin{array}{l}\text { RG. } \\
\text { Komputer 1 }\end{array}$ & 18 & 7 & 126 & 500 & 0,8 \\
\hline
\end{tabular}

Tinggi lampu terhadap bidang kerja:

$h=t$-tinggi media kerja

$h=3,8-0,8$ meter

$=3$ meter

$k=\frac{p \times l}{h(p+l)}$

$=\frac{18 \times 7}{3(18+7)}$

$=\frac{126}{75}$

$=1,68$

Faktor-faktor refleksi (tabel 2.3)

$r_{p}=$ faktor refleksi langit-langit $(0,5)$

$r_{W}=$ faktor refleksi dinding $(0,3)$

$r_{m}=$ faktor refleksi bidang pengukuran $(0,1)$

Untuk :

$\mathrm{k}=1,68$

$\mathrm{k}_{1}=1,5$

$\mathrm{k}_{2}=2$

$\eta_{1}=0,54$

$\eta_{2}=0,59$

Efisiensi penerangan untuk nilai Indeks Ruang $(k)$ adalah: $\eta=\eta_{1}+\frac{k-k_{1}}{k_{2}-k_{1}}\left(\eta_{2}-\eta_{1}\right)$

$\eta=0,54+\frac{1,68-1,5}{2-1.5}(0,59-0,54)$

$=0,54+0,36 \times 0.05$

$\eta=0,558$

Menggunakan lampu TL $2 \times 36$ watt, $(2 \times 2700$ lumen $)$, $\cos \varphi$ pada lampu TL 0,85

$$
\begin{aligned}
n & =\frac{E \times A}{\Phi \times \eta \times d} \\
& =\frac{500 \times 126}{5400 \times 0,558 \times 0,8} \\
& =\frac{63000}{2561,22} \\
& =24 \text { buah lampu }
\end{aligned}
$$

Maka total daya penerangan pada ruang komputer 1 : $24 \times 36=864$ watt 
Pembagian Grub

Perhitungan Kapasitas Skering Pada Lantai 1 Blok A

$$
\begin{aligned}
I_{n} & =\frac{}{V \times \cos \varphi} \\
& =\frac{6608}{220 \times 0,85} \\
& =\frac{6608}{187} \\
& =35,33 \text { Ampere } \approx 35 \text { Ampere }
\end{aligned}
$$

Kemampuan Hantar Arus

$$
\mathrm{KHA}=125 \% \times 35,33
$$

\begin{tabular}{|c|c|c|c|c|c|c|c|c|c|c|c|}
\hline No & Ruangan & E & A & $\mathrm{k}$ & $\mathrm{k}_{1}$ & $\mathrm{k}_{2}$ & $\eta_{1}$ & $\eta_{2}$ & $\eta$ & $\mathrm{n}$ & Daya \\
\hline 1 & $\begin{array}{l}\text { RG.Kepala Lab } \\
\text { Biologi }\end{array}$ & 1000 & 36 & 1.00 & 1 & 1.2 & 0.45 & 0.49 & 0.5 & 18 & 648 \\
\hline 2 & $\begin{array}{l}\text { RG.Lab. } \\
\text { Biologi }\end{array}$ & 500 & 162 & 2.00 & 2 & 2.5 & 0.59 & 0.63 & 0.6 & 30 & 1080 \\
\hline 3 & $\begin{array}{l}\text { RG.Laboran } \\
\text { Kimia \& } \\
\text { Biologi }\end{array}$ & 1000 & 61.2 & 1.26 & 1.2 & 1.5 & 0.49 & 0.54 & 0.5 & 26 & 936 \\
\hline 4 & RG.Lab. Kimia & 500 & 108 & 1.71 & 1.5 & 2 & 0.54 & 0.59 & 0.6 & 20 & 720 \\
\hline 5 & $\begin{array}{l}\text { RG.Admin } \\
\text { Biologi }\end{array}$ & 1000 & 36 & 1.00 & 1 & 1.2 & 0.45 & 0.49 & 0.5 & 18 & 648 \\
\hline 6 & $\begin{array}{l}\text { RG.Admin } \\
\text { Kimia }\end{array}$ & 1000 & 36 & 1.00 & 1 & 1.2 & 0.45 & 0.49 & 0.5 & 18 & 648 \\
\hline 7 & $\begin{array}{l}\text { RG.Instrumen } \\
\text { Lab Kimia }\end{array}$ & 1000 & 54 & 1.20 & 1.2 & 1.5 & 0.49 & 0.54 & 0.5 & 24 & 864 \\
\hline 8 & $\begin{array}{l}\text { RG.Kepala Lab } \\
\text { Kimia }\end{array}$ & 1000 & 36 & 1.00 & 1 & 1.2 & 0.45 & 0.49 & 0.5 & 18 & 648 \\
\hline 9 & Koridor 1 & 100 & 86.4 & 1.04 & 1 & 1.2 & 0.45 & 0.49 & 0.5 & 4 & 144 \\
\hline 10 & $\begin{array}{l}\text { Teras Kiri } \\
\text { Kanan }\end{array}$ & 100 & 36 & 1.00 & 1 & 1.2 & 0.45 & 0.49 & 0.5 & 2 & 72 \\
\hline 11 & Pantry & 250 & 4.5 & 0.33 & 0 & 0.5 & 0 & 0.16 & 0.1 & 8 & 160 \\
\hline 12 & 2 Toilet & 100 & 3 & 0.29 & 0 & 0.5 & 0 & 0.16 & 0.1 & 2 & 40 \\
\hline \multicolumn{11}{|c|}{ Total Daya (watt) } & 6608 \\
\hline
\end{tabular}$$
=44,16 \mathrm{~A}
$$

\section{Luas Penampang Kabel}

$$
\begin{aligned}
A & =\frac{2 \times l \times l \times \cos \varphi}{\gamma \times u} \\
& =\frac{2 \times 25 \times 35,33 \times 0,8}{56,2 \times 10^{6} \times 4 \% \times 220} \\
& =\frac{1413,20}{494,56} \\
& =2,85 \times 10^{-6} \text { meter }^{2} \\
& =2,85 \mathrm{~mm}^{2} \approx 2,5 \mathrm{~mm}^{2}
\end{aligned}
$$

Tabel 4

Hasil Perhitungan Lantai 1 Blok A

Perhitungan Kapasitas Skering Pada Lantai 1 Blok B

$$
\begin{aligned}
I_{n} & =\frac{P \times \cos \varphi}{V 472} \\
& =\frac{520 \times 0,85}{220} \\
& =\frac{5472}{187} \\
& =29,26 \text { Ampere } \approx 35 \text { Ampere }
\end{aligned}
$$

Kemampuan Hantar Arus

$\mathrm{KHA}=125 \% \times 29,26$

$$
=36,57 \mathrm{~A}
$$

\begin{tabular}{|c|c|c|c|c|c|c|c|c|c|c|c|}
\hline \multicolumn{12}{|c|}{ Hasil Perhitungan Lantai 1 Bl } \\
\hline No & Ruangan & E & A & $\mathrm{k}$ & $\mathrm{k}_{1}$ & $\mathrm{k}_{2}$ & $\eta_{1}$ & $\eta_{2}$ & $\eta$ & $\mathrm{n}$ & Daya \\
\hline 1 & $\begin{array}{l}\text { RG.Lab.Fisika } \\
\text { Dasar }\end{array}$ & 500 & 162 & 2.00 & 2 & 2.5 & 0.59 & 0.63 & 0.6 & 30 & 1080 \\
\hline 2 & $\begin{array}{l}\text { RG.Laboran } \\
\text { Fisika }\end{array}$ & 1000 & 30.6 & 0.77 & 0.6 & 0.8 & 0.30 & 0.38 & 0.4 & 18 & 648 \\
\hline 3 & RG.Komputer 4 & 500 & 135 & 1.88 & 1.5 & 2 & 0.54 & 0.59 & 0.6 & 26 & 936 \\
\hline 4 & $\begin{array}{l}\text { RG.Instruktur } \\
\text { Lab Komputer }\end{array}$ & 1000 & 45 & 1.07 & 1 & 1.2 & 0.45 & 0.49 & 0.5 & 20 & 720 \\
\hline 5 & $\begin{array}{l}\text { RG.Kepala Lab } \\
\text { Komputer }\end{array}$ & 1000 & 36 & 1.00 & 1 & 1.2 & 0.45 & 0.49 & 0.5 & 18 & 648 \\
\hline 6 & $\begin{array}{l}\text { RG.Admin } \\
\text { komputer }\end{array}$ & 1000 & 36 & 1.00 & 1 & 1.2 & 0.45 & 0.49 & 0.5 & 18 & 648 \\
\hline 7 & $\begin{array}{l}\text { RG.Kepala Lab } \\
\text { Fisika }\end{array}$ & 1000 & 36 & 1.00 & 1 & 1.2 & 0.45 & 0.49 & 0.5 & 18 & 648 \\
\hline 8 & $\begin{array}{l}\text { RG.Admin } \\
\text { Fisika Dasar }\end{array}$ & 1000 & 36 & 1.00 & 1 & 1.2 & 0.45 & 0.49 & 0.5 & 18 & 648 \\
\hline 9 & Koridor 2 & 100 & 86.4 & 1.04 & 1 & 1.2 & 0.45 & 0.49 & 0.5 & 4 & 144 \\
\hline 10 & Pantry & 250 & 4.5 & 0.33 & 0 & 0.5 & 0 & 0.16 & 0.1 & 8 & 160 \\
\hline 11 & Toilet & 100 & \begin{tabular}{l|l}
3 & \\
\end{tabular} & \begin{tabular}{l|l|l}
0.29 \\
\end{tabular} & 0 & 0.5 & 0 & 0.16 & 0.1 & 2 & 40 \\
\hline \multicolumn{11}{|c|}{ Total Daya (watt) } & 6320 \\
\hline
\end{tabular}

Luas Penampang Kabel

$$
\begin{aligned}
A & =\frac{2 \times l \times l \times \cos \varphi}{\gamma \times u} \\
& =\frac{2 \times 25 \times 29,26 \times 0,8}{56,2 \times 10^{6} \times 4 \% \times 220}
\end{aligned}
$$

$$
\begin{aligned}
& =\frac{1170,40}{494,56} \\
& =2,36 \times 10^{-6} \text { meter }^{2} \\
& =2,36 \mathrm{~mm}^{2} \approx 2,5 \mathrm{~mm}^{2}
\end{aligned}
$$

Tabel 5

Hasil Perhitungan Lantai 1 Blok B

\begin{tabular}{|c|l|c|c|c|c|c|c|c|c|c|c|}
\hline No & \multicolumn{1}{|c|}{ Ruangan } & E & $\mathrm{A}$ & $\mathrm{k}$ & $\mathrm{k}_{1}$ & $\mathrm{k}_{2}$ & $\eta_{1}$ & $\eta_{2}$ & $\eta$ & $\mathrm{n}$ & Daya \\
\hline 1 & RG.Komputer 1 & 500 & 126 & 1.68 & 1.5 & 2 & 0.54 & 0.59 & 0.6 & 24 & 864 \\
\hline 2 & RG.Komputer 2 & 500 & 126 & 1.68 & 1.5 & 2 & 0.54 & 0.59 & 0.6 & 24 & 864 \\
\hline 3 & RG.Komputer 3 & 500 & 126 & 1.31 & 1.2 & 1.5 & 0.49 & 0.54 & 0.5 & 26 & 936 \\
\hline 4 & $\begin{array}{l}\text { RG.Kuliah } \\
\text { Bersama }\end{array}$ & 500 & 84 & 1.47 & 1.2 & 1.5 & 0.49 & 0.54 & 0.5 & 18 & 648 \\
\hline 5 & RG. Dosen & 1000 & 42 & 1.08 & 1 & 1.2 & 0.45 & 0.49 & 0.5 & 20 & 720 \\
\hline 6 & Teras Utama & 100 & 49 & 1.17 & 1 & 1.2 & 0.45 & 0.49 & 0.5 & 2 & 72 \\
\hline 7 & Hall Lobby & 100 & 252 & 2.55 & 2.5 & 3 & 0.63 & 0.65 & 0.6 & 8 & 288 \\
\hline 8 & RG. Security & 250 & 12.25 & 0.58 & 0.5 & 0.6 & 0.16 & 0.19 & 0.2 & 14 & 280 \\
\hline 9 & Gudang & 250 & 21 & 0.70 & 0.6 & 0.8 & 0.19 & 0.24 & 0.2 & 20 & 400 \\
\hline 10 & 2 Pantry & 250 & 4.5 & 0.33 & 0 & 0.5 & 0 & 0.16 & 0.1 & 8 & 160 \\
\hline 11 & 2 Toilet & 100 & 3 & 0.29 & 0 & 0.5 & 0 & 0.16 & 0.1 & 2 & 40 \\
\hline 12 & RG. Panel & 250 & 5.25 & 0.35 & 0 & 0.5 & 0 & 0.16 & 0.1 & 10 & 200 \\
\hline & \multicolumn{7}{|c|}{ Total Daya (watt) } \\
\hline
\end{tabular}

Perhitungan Kapasitas Skering Pada Lantai 1 Blok C

$$
\begin{aligned}
I_{n} & =\frac{P}{V \times \cos \varphi} \\
& =\frac{6320}{220 \times 0,85} \\
& =\frac{6320}{187} \\
& =33,79 \text { Ampere } \approx 35 \text { Ampere }
\end{aligned}
$$

Kemampuan Hantar Arus

$\mathrm{KHA}=125 \% \times 33,79$

$$
=42,23 \mathrm{~A}
$$

Luas Penampang Kabel

$$
\begin{aligned}
A & =\frac{2 \times l \times l \times \cos \varphi}{\gamma \times u} \\
& =\frac{2 \times 25 \times 33,79 \times 0,8}{56,2 \times 10^{6} \times 4 \% \times 220} \\
& =\frac{1351,60}{494,56} \\
& =2,73 \times 10^{-6} \text { meter }^{2} \\
& =2,73 \mathrm{~mm}^{2} \approx 2,5 \mathrm{~mm}^{2}
\end{aligned}
$$

Tabel 6

Hasil Perhitungan Lantai 1 Blok C 
B. Perhitungan Instalasi pada Gedung Lantai 2

\section{Ruang MKWU 1}

\begin{tabular}{|l|c|c|c|c|c|}
\hline Ruangan & $\begin{array}{c}\text { Panjang } \\
\text { Ruangan (m) }\end{array}$ & $\begin{array}{c}\text { Lebar } \\
\text { Ruangan } \\
(\mathrm{m})\end{array}$ & $\begin{array}{c}\text { Luas } \\
\text { Ruangan } \\
\left(\mathrm{m}^{2}\right)\end{array}$ & $\begin{array}{c}\text { Intensitas } \\
\text { Penerangan (E) } \\
(\text { Lux })\end{array}$ & $\begin{array}{c}\text { Faktor } \\
\text { Penyusutan } \\
(\mathrm{d})\end{array}$ \\
\hline $\begin{array}{l}\text { Ruang } \\
\text { MKWU 1 }\end{array}$ & 7,2 & 18 & 129,6 & 500 & 0,8 \\
\hline
\end{tabular}

Tinggi lampu terhadap bidang kerja:

$h=t$-tinggi media kerja

$h=3,8-0,8$ meter

$=3$ meter

$k=\frac{p \times l}{h(p+l)}$

$$
\begin{aligned}
& =\frac{18 \times 7,2}{3(18+7,2)} \\
& =\frac{129,6}{75,6} \\
& =1,71
\end{aligned}
$$

Faktor-faktor refleksi (tabel 2.3)

$r_{p}=$ faktor refleksi langit-langit $(0,5)$

$r_{W}=$ faktor refleksi dinding $(0,3)$

$r_{\mathrm{m}}=$ faktor refleksi bidang pengukuran $(0,1)$

Untuk :

$\mathrm{k}=1,71$

$\mathrm{k}_{1}=1,5$

$\mathrm{k}_{2}=2$

$\eta_{1}=0,54$

$\eta_{2}=0,59$

Efisiensi penerangan untuk nilai Indeks Ruang $(k)$ adalah:

$$
\begin{aligned}
\eta & =\eta_{1}+\frac{k-k_{1}}{k_{2}-k_{1}}\left(\eta_{2}-\eta_{1}\right) \\
\eta & =0,54+\frac{1,1,5}{2-1,5}(0,59-0,54) \\
& =0,54+0,42 \times 0,05 \\
\eta & =0,561
\end{aligned}
$$

Menggunakan lampu TL $2 \times 36$ watt, $(2 \times 2700$ lumen $)$, $\cos \varphi$ pada lampu TL 0,85

$$
\begin{aligned}
n & =\frac{E \times A}{\Phi \times \eta \times d} \\
& =\frac{500 \times 129,6}{5400 \times 0,561 \times 0,8} \\
& =\frac{64800}{2423,52} \\
& =24 \text { buah lampu }
\end{aligned}
$$

\begin{tabular}{|c|c|c|c|c|c|c|c|c|c|c|c|}
\hline & \multicolumn{9}{|c|}{ ungan Lamtar 21} & & \\
\hline No & Ruangan & E & A & $\mathrm{k}$ & $\mathrm{k}_{1}$ & $\mathrm{k}_{2}$ & $\eta_{1}$ & $\mathrm{\eta}_{2}$ & $\eta$ & $\mathrm{n}$ & Daya \\
\hline 1 & RG.MKWU 1 & 500 & 129.6 & 1.71 & 1.5 & 2 & 0.54 & \begin{tabular}{|l|}
0.59 \\
\end{tabular} & \begin{tabular}{|l|}
0.561 \\
\end{tabular} & 24 & 864 \\
\hline 2 & RG.MKWU 2 & 500 & 86.4 & 1.50 & 1.5 & 2 & 0.54 & \begin{tabular}{|l|}
0.59 \\
\end{tabular} & 0.540 & 18 & 648 \\
\hline 3 & RG.MKWU 3 & 500 & 86.4 & 1.50 & 1.5 & 2 & 0.54 & \begin{tabular}{|l|}
0.59 \\
\end{tabular} & \begin{tabular}{|l|}
0.540 \\
\end{tabular} & 18 & 648 \\
\hline 4 & RG.MKWU 4 & 500 & 86.4 & 1.50 & 1.5 & 2 & 0.54 & \begin{tabular}{|l|}
0.59 \\
\end{tabular} & 0.540 & 18 & 648 \\
\hline 5 & $\begin{array}{l}\text { RG.Kepala } \\
\text { Pengelola }\end{array}$ & 1000 & 86.4 & 1.50 & 1.5 & 2 & 0.54 & $\mid 0.59$ & 0.540 & 34 & 1224 \\
\hline 6 & Gudang & 50 & 18 & 0.67 & 0.6 & 0.8 & 0.19 & 0.24 & \begin{tabular}{|l|l|l|l|l|l}
0.207 &
\end{tabular} & 4 & 80 \\
\hline 7 & Koridor & 100 & 86.4 & 1.04 & 1 & 1.2 & 0.45 & \begin{tabular}{|l|}
0.49 \\
\end{tabular} & \begin{tabular}{|l|l|} 
& 0.459 \\
\end{tabular} & 4 & 144 \\
\hline \multicolumn{11}{|c|}{ Total Daya (watt) } & 3392 \\
\hline
\end{tabular}

Maka total daya penerangan pada ruang MKWU 1 :

$24 \times 36=864$ watt

\section{Pembagian Grub}

Perhitungan Kapasitas Skering Pada Lantai 2 Blok A

$$
\begin{aligned}
I_{n} & =\frac{P}{V \times \cos \varphi} \\
& =\frac{3392}{220 \times 0,85} \\
& =\frac{3392}{187} \\
& =18.13 \text { Ampere } \approx 20 \text { Ampere }
\end{aligned}
$$

Kemampuan Hantar Arus

$\mathrm{KHA}=125 \% \times 18,13$

$$
=22,66 \mathrm{~A}
$$

Luas Penampang Kabel

$$
\begin{aligned}
A & =\frac{2 \times l \times I \times \cos \varphi}{\gamma \times u} \\
& =\frac{2 \times 25 \times 18,13 \times 0,8}{56,2 \times 10^{6} \times 4 \% \times 220} \\
& =\frac{725,2}{494,56} \\
& =1,46 \times 10^{-6} \text { meter }^{2} \\
& =1,46 \mathrm{~mm}^{2} \approx 1,5 \mathrm{~mm}^{2}
\end{aligned}
$$

Tabel 7

Hasil Perhitungan Lantai 2 Blok A

\section{Perhitungan Kapasitas Skering Pada Lantai 2 Blok B}

$$
\begin{aligned}
I_{n} & =\frac{P}{V \times \cos \varphi} \\
& =\frac{5104}{220 \times 0,85} \\
& =\frac{5104}{187} \\
& =27,29 \text { Ampere } \approx 35 \text { Ampere }
\end{aligned}
$$

Kemampuan Hantar Arus

KHA $=125 \% \times 27,29$

$$
=34,11 \mathrm{~A}
$$

Luas Penampang Kabel

$$
\begin{aligned}
A & =\frac{2 \times l \times I \times \cos \varphi}{\gamma \times u} \\
& =\frac{2 \times 25 \times 27,29 \times 0,8}{56,2 \times 10^{6} \times 4 \% \times 220} \\
& =\frac{1091,60}{494,56} \\
& =2,2 \times 10^{-6} \mathrm{~meter}^{2} \\
& =2,2 \mathrm{~mm}^{2} \approx 2,5 \mathrm{~mm}^{2}
\end{aligned}
$$

Tabel 8

Hasil Perhitungan Lantai 2 Blok B

\begin{tabular}{|c|l|c|c|c|c|c|c|c|c|c|c|}
\hline No & \multicolumn{1}{|c|}{ Ruangan } & $\mathrm{E}$ & $\mathrm{A}$ & $\mathrm{k}$ & $\mathrm{k}_{1}$ & $\mathrm{k}_{2}$ & $\mathrm{\eta}_{1}$ & $\mathrm{\eta}_{2}$ & $\mathrm{\eta}$ & $\mathrm{n}$ & Daya \\
\hline 1 & RG.MKWU 9 & 500 & 189 & 2.21 & 2 & 2.5 & 0.59 & 0.63 & 0.607 & 34 & 1224 \\
\hline 2 & $\begin{array}{l}\text { RG.MKWU } \\
10\end{array}$ & 500 & 189 & 2.21 & 2 & 2.5 & 0.59 & 0.63 & 0.607 & 34 & 1224 \\
\hline 3 & RG. Dosen & 1000 & 42 & 1.08 & 1 & 1.2 & 0.45 & 0.49 & 0.465 & 20 & 720 \\
\hline 4 & RG. Tunggu & 100 & 84 & 1.47 & 1.2 & 1.5 & 0.49 & 0.54 & 0.536 & 4 & 144 \\
\hline 5 & $\begin{array}{l}\text { RG. Admin } \\
\text { Pengelola }\end{array}$ & 1000 & 84 & 1.47 & 1.2 & 1.5 & 0.49 & 0.54 & 0.536 & 34 & 1224 \\
\hline 6 & Musholla & 250 & 84 & 1.47 & 1.2 & 1.5 & 0.49 & 0.54 & 0.536 & 8 & 288 \\
\hline 7 & 4 Pantry & 250 & 4.5 & 0.33 & 0 & 0.5 & 0 & 0.16 & 0.107 & 8 & 160 \\
\hline 8 & 2 Toilet & 100 & 3 & 0.29 & 0 & 0.5 & 0 & 0.16 & 0.091 & 2 & 40 \\
\hline 9 & RG. Panel & 100 & 5.25 & 0.35 & 0 & 0.5 & 0 & 0.16 & 0.112 & 4 & 80 \\
\hline
\end{tabular}




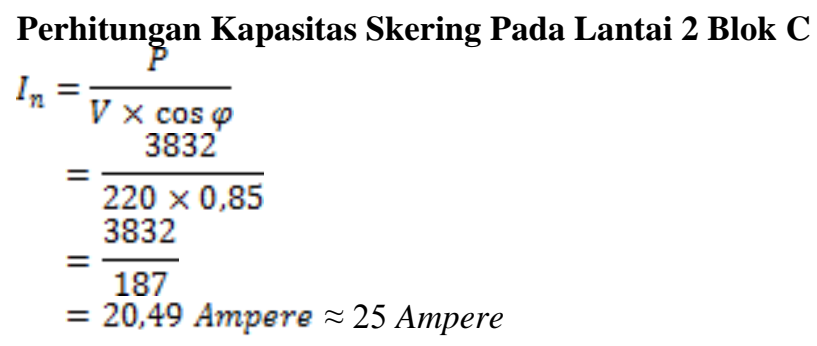

Kemampuan Hantar Arus

$\mathrm{KHA}=125 \% \times 20,49$ $=25,61 \mathrm{~A}$

Luas Penampang Kabel

$$
\begin{aligned}
A & =\frac{2 \times l \times I \times \cos \varphi}{\gamma \times u} \\
& =\frac{2 \times 25 \times 20,49 \times 0,8}{56,2 \times 10^{6} \times 4 \% \times 220} \\
& =\frac{819,60}{494,56} \\
& =1,65 \times 10^{-6} \text { meter }^{2} \\
& =1,65 \mathrm{~mm}^{2} \approx 2,5 \mathrm{~mm}^{2}
\end{aligned}
$$

Tabel 9

Hasil Perhitungan Lantai 2 Blok C

\begin{tabular}{|c|l|c|c|c|c|c|c|c|c|c|c|}
\hline No & \multicolumn{1}{|c|}{ Ruangan } & $\mathrm{E}$ & $\mathrm{A}$ & $\mathrm{k}$ & $\mathrm{k}_{1}$ & $\mathrm{k}_{2}$ & $\mathrm{\eta}_{1}$ & $\mathrm{\eta}_{2}$ & $\mathrm{\eta}$ & $\mathrm{n}$ & Daya \\
\hline 1 & RG.MKWU 5 & 500 & 86.4 & 1.50 & 1.5 & 2 & 0.54 & 0.59 & 0.540 & 18 & 648 \\
\hline 2 & RG.MKWU 6 & 500 & 86.4 & 1.50 & 1.5 & 2 & 0.54 & 0.59 & 0.540 & 18 & 648 \\
\hline 3 & RG.MKWU 7 & 500 & 86.4 & 1.50 & 1.5 & 2 & 0.54 & 0.59 & 0.540 & 18 & 648 \\
\hline 4 & RG.MKWU 8 & 500 & 86.4 & 1.50 & 1.5 & 2 & 0.54 & 0.59 & 0.540 & 18 & 648 \\
\hline 5 & $\begin{array}{l}\text { Tempat } \\
\text { Wudhu }\end{array}$ & 100 & 86.4 & 1.50 & 1.5 & 2 & 0.36 & 0.59 & 0.360 & 6 & 216 \\
\hline 6 & $\begin{array}{l}\text { RG.Admin } \\
\text { Perkuliahan }\end{array}$ & 1000 & 43.2 & 1.09 & 1 & 1.2 & 0.29 & 0.49 & 0.381 & 24 & 864 \\
\hline 7 & Gudang & 250 & 18 & 0.67 & 0.6 & 0.8 & 0.19 & 0.38 & 0.253 & 4 & 80 \\
\hline 8 & Koridor 2 & 100 & 86.4 & 1.04 & 1 & 1.2 & 0.45 & 0.49 & 0.459 & 4 & 80 \\
\hline \multicolumn{8}{|c|}{ Total Daya (watt) } \\
\hline
\end{tabular}

\section{Perhitungan Top Floor}

\begin{tabular}{|l|c|c|c|c|c|}
\hline Ruangan & $\begin{array}{c}\text { Panjang } \\
\text { Ruangan }(\mathrm{m})\end{array}$ & $\begin{array}{c}\text { Lebar } \\
\text { Ruangan } \\
(\mathrm{m})\end{array}$ & $\begin{array}{c}\text { Luas } \\
\text { Ruangan } \\
\left(\mathrm{m}^{2}\right)\end{array}$ & $\begin{array}{c}\text { Intensitas } \\
\text { Penerangan (E) } \\
(\text { Lux })\end{array}$ & $\begin{array}{c}\text { Faktor } \\
\text { Penyusutan } \\
(\mathrm{d})\end{array}$ \\
\hline Blok A & 6 & 18 & 108 & 250 & 0,8 \\
\hline Blok B & 12 & 21 & 252 & 250 & 0,8 \\
\hline Blok C & 6 & 18 & 108 & 250 & 0,8 \\
\hline
\end{tabular}

\section{Blok A}

Tinggi lampu terhadap bidang kerja:

$$
\begin{aligned}
h & =t-0,8 \text { meter } \\
h & =3,8-0,8 \text { meter } \\
& =3 \text { meter } \\
k & =\frac{p \times l}{h(p+l)} \\
& =\frac{6 \times 18}{3(6+18)} \\
& =\frac{108}{72} \\
& =1,5
\end{aligned}
$$

Faktor-faktor refleksi (tabel 2.3)

$r_{p}=$ faktor refleksi langit-langit $(0,5)$

$\tau_{W}=$ faktor refleksi dinding $(0,3)$

$r_{m}=$ faktor refleksi bidang pengukuran $(0,1)$

Untuk :

$\mathrm{k}=1,5$

$\mathrm{k}_{1}=1,5$

$\mathrm{k}_{2}=2$ $\eta_{1}=0,54$

$\eta_{2}=0,59$

Efisiensi penerangan untuk nilai Indeks Ruang $(k)$ adalah:

$$
\begin{aligned}
\eta & =\eta_{1}+\frac{k-k_{1}}{k_{2}-k_{1}}\left(\eta_{2}-\eta_{1}\right) \\
\eta & =0,54+\frac{1,5-1,5}{2-1,5}(0,59-0.54) \\
& =0,54+0 \times 0,05 \\
\eta & =0,54
\end{aligned}
$$

Menggunakan lampu SL $1 \times 20$ watt, $(1 \times 1500$ lumen $)$

$$
\begin{aligned}
n & =\frac{E \times A}{\Phi \times \eta \times d} \\
& =\frac{100 \times 108}{5400 \times 0,54 \times 0,8} \\
& =\frac{10800}{2332,8} \\
& =4 \text { buah lampu }
\end{aligned}
$$

Maka total daya penerangan pada Blok A:

$4 \times 20=80$ watt

2. Blok B

Tinggi lampu terhadap bidang kerja:

$h=t-0,8$ meter

$h=3,8-0,8$ meter

$=3$ meter

$$
\begin{aligned}
k & =\frac{p \times l}{h(p+l)} \\
& =\frac{12 \times 21}{3(12+21)} \\
& =\frac{252}{99} \\
& =2,5
\end{aligned}
$$

Faktor-faktor refleksi (tabel 2.3)

$r_{p}=$ faktor refleksi langit-langit $(0,5)$

$x_{W}=$ faktor refleksi dinding $(0,3)$

$r_{m}=$ faktor refleksi bidang pengukuran $(0,1)$

Untuk :

$\mathrm{k}=2,5$

$\mathrm{k}_{1}=2,5$

$\mathrm{k}_{2}=3$

$\eta_{1}=0,63$

$\eta_{2}=0,65$

Efisiensi penerangan untuk nilai Indeks Ruang $(k)$ adalah:

$$
\begin{aligned}
\eta & =\eta_{1}+\frac{k-k_{1}}{k_{2}-k_{1}}\left(\eta_{2}-\eta_{1}\right) \\
\eta & =0,63+\frac{2,5-2,5}{a-2,5}(0,65-0,63) \\
& =0,63+0 \times 0,02 \\
\eta & =0,63
\end{aligned}
$$

Menggunakan lampu SL $1 \times 20$ watt, $(1 \times 1500$ lumen $)$

$$
\begin{aligned}
n & =\frac{E \times A}{\Phi \times \eta \times d} \\
& =\frac{100 \times 252}{5400 \times 0,63 \times 0,8}
\end{aligned}
$$




$$
\begin{aligned}
& =\frac{25000}{2721,6} \\
& =8 \text { buah lampu }
\end{aligned}
$$

Maka total daya penerangan pada Blok B:

$$
8 \times 20=160 \text { watt }
$$

3. Blok C

Tinggi lampu terhadap bidang kerja:

$$
\begin{aligned}
& h=t-0,8 \text { meter } \\
& h=3,8-0,8 \text { meter } \\
& =3 \text { meter } \\
& k=\frac{p \times l}{h(p+l)} \\
& =\frac{6 \times 18}{3(6+18)} \\
& =\frac{108}{72} \\
& =1,5
\end{aligned}
$$

Faktor-faktor refleksi (tabel 2.3)

$r_{p}=$ faktor refleksi langit-langit $(0,5)$

$r_{W}=$ faktor refleksi dinding $(0,3)$

$r_{\mathrm{m}}=$ faktor refleksi bidang pengukuran $(0,1)$

Untuk :

$\mathrm{k}=1,5$

$\mathrm{k}_{1}=1,5$

$\mathrm{k}_{2}=2$

$\eta_{1}=0,54$

$\eta_{2}=0,59$

Efisiensi penerangan untuk nilai Indeks Ruang $(k)$ adalah:

$$
\begin{aligned}
\eta & =\eta_{1}+\frac{k-k_{1}}{k_{2}-k_{1}}\left(\eta_{2}-\eta_{1}\right) \\
\eta & =0,54+\frac{1,5-1,5}{2-1,5}(0,59-0.54) \\
& =0,54+0 \times 0,05 \\
\eta & =0,54
\end{aligned}
$$

Menggunakan lampu SL $1 \times 20$ watt, $(1 \times 1500$ lumen $)$

$$
\begin{aligned}
n & =\frac{E \times A}{\Phi \times \eta \times d} \\
& =\frac{100 \times 108}{5400 \times 0,54 \times 0,8} \\
& =\frac{10800}{2332,8} \\
& =4 \text { buah lampu }
\end{aligned}
$$

Maka total daya penerangan pada Blok A:

$4 \times 20=80$ watt

Total Daya pada Top Floor

$80+160+80=320$ watt

Perhitungan Kapasitas Skering Pada Top Floor

$$
\begin{aligned}
& I_{n}=\frac{P}{V \times \cos \varphi} \\
& =\frac{320}{220 \times 0,85} \\
& =1_{s} 71 \text { Ampere } \approx 2 \text { Ampere }
\end{aligned}
$$

Kemampuan Hantar Arus

$\mathrm{KHA}=125 \% \times 1,71$

$$
=2,13 \mathrm{~A}
$$

Luas Penampang Kabel

$$
\begin{aligned}
A & =\frac{2 \times l \times I \times \cos \varphi}{\gamma \times u} \\
& =\frac{2 \times 50 \times 1,71 \times 0,8}{56,2 \times 10^{6} \times 4 \% \times 220} \\
& =\frac{136,8}{494,56} \\
& =0,27 \times 10^{-6} \mathrm{~meter}^{2} \\
& =0,27 \mathrm{~mm}^{2} \approx 0,3 \mathrm{~mm}^{2}
\end{aligned}
$$

Berdasarkan PUIL 2000 ukuran minimum Penampang Kabel adalah 1,5 $\mathrm{mm}^{2}$. Maka Luas Penampang Kabel = $1,5 \mathrm{~mm}^{2}$

Tabel 10

Hasil Perhitungan Top Floor

\begin{tabular}{|c|c|c|c|c|c|c|c|c|c|c|c|}
\hline No & Ruangan & E & $\mathrm{A}$ & $\mathrm{k}$ & $\mathrm{k}_{1}$ & $\mathrm{k}_{2}$ & $\mathrm{\eta}_{1}$ & $\mathrm{\eta}_{2}$ & $\mathrm{\eta}$ & $\mathrm{n}$ & Daya \\
\hline 1 & BLOK A & 100 & 108 & 1.50 & 1.5 & 2 & 0.54 & 0.59 & 0.540 & 4 & 80 \\
\hline 2 & BLOK B & 100 & 252 & 2.55 & 2.5 & 3 & 0.63 & 0.65 & 0.632 & 8 & 160 \\
\hline 3 & BLOK C & 100 & 108 & 1.50 & 1.5 & 2 & 0.54 & 0.59 & 0.540 & 4 & 80 \\
\hline \multicolumn{10}{|c|}{ Total Daya (watt) } \\
\hline
\end{tabular}

D. Perhitungan Susut Tegangan

Total daya penerangan pada seluruh Gedung adalah:

$$
\begin{aligned}
I_{n} & =\frac{P}{V \times \cos \varphi} \\
& =\frac{31048}{220 \times 0,85} \\
& =\frac{31048}{187} \\
& =166,03 \text { Ampere } \approx 3 \times 50 \text { Ampere }
\end{aligned}
$$

Susut Tegangan

$$
\begin{aligned}
\Delta V & =\left[2 \times I \times\left(R^{t} \times \cos \varphi+X^{t}{ }_{L} \times \sin \varphi\right) \times l\right] / 1000 \\
& =\frac{[2 \times 166,03 \times(7,14 \times 0,8+0,104 \times 0,6) \times 50]}{1000} \\
& =\frac{95872,3}{1000} \\
& =95,8 \\
& =\frac{95,8}{220} \times 100 \% \\
& =0,4 \%
\end{aligned}
$$

\section{KESIMPULAN}

Berdasarkan hasil perhitungan pada perencanaan instalasi penerangan didapat hasil:

1. Daya pada Lantai 1 sebesar 18400 watt dengan arus nomilal masing-masing blok adalah sebesar 35 Ampere dan kemampuan hantar arus (KHA) pada masing-masing blok adalah $(44,15)$, $(36,57)$, dan $(42,23)$ Ampere. Sedangkan untuk luas penampang kabel masing-masing blok menggunakan kabel 2,5 $\mathrm{mm}^{2}$.

2. Daya pada Lantai 2 sebesar 12328 watt dengan arus nomilal masing-masing blok adalah sebesar 20, 35, dan 25 Ampere, untuk kemampuan hantar arus (KHA) pada masing-masing blok adalah $(22,66),(34,11)$, dan $(25,61)$ Ampere. Sedangkan untuk luas penampang 
kabel masing-masing blok menggunakan kabel 1,5 $\mathrm{mm}^{2}$ untuk blok A dan 2,5 $\mathrm{mm}^{2}$ untuk blok B dan C

3. Daya pada Top Floor sebesar 320 watt dengan arus nomilal adalah sebesar 2 Ampere dan kemampuan hantar arus (KHA) adalah 2,13 Ampere. Sedangkan untuk luas penampang kabel menggunakan kabel 1,5 $\mathrm{mm}^{2}$.

4. Susut tegangan yang didapatkan berdasarkan hasil perhitungan adalah sebesar $0,4 \%$

\section{REFERENSI}

[1] Setiawan, E., Harten, P.V., 1986. Instalasi Listrik Arus Kuat. Binacipta, Jakarta.

[2] Badan Standarisasi Nasional, 2000. Persyaratan Umum Instalasi Listrik (PUIL) 2000. Yayasan Persyaratan Umum Instalasi Listrik (PUIL) 2000

[3] P. van. Harten, ir. E. Setiawan, 1991. Instalasi Listrik Arus Kuat Jilid 1, 2, 3 Percetakan Binacipta Bandung.

[4] Instalasi Penerangan: Teori Dasar Pencahayaan, 2008. . Instal. Penerangan. 